\title{
Glutamine regulates expression of key transcription factor, signal transduction, metabolic gene, and protein expression in a clonal pancreatic $\beta$-cell line
}

\author{
Mary Corless, Aoife Kiely, Neville H McClenaghan ${ }^{\mathbf{1}}$, Peter R Flatt ${ }^{\mathbf{1}}$ and Philip Newsholme \\ School of Biomolecular and Biomedical Sciences, Conway Institute, University College Dublin, Belfield, Dublin 4, Ireland \\ ${ }^{1}$ School of Biomedical Sciences, University of Ulster, Coleraine, Northern Ireland, UK \\ (Requests for offprints should be addressed to P Newsholme; Email: philip.newsholme@ucd.ie)
}

\begin{abstract}
We have investigated the effects of prolonged exposure ( $24 \mathrm{~h})$ to the amino acid L-glutamine, on gene and protein expression using clonal BRIN-BD11 $\beta$-cells. Expression profiling of BRIN-BD11 cells was performed using oligonucleotide microarray analysis. Culture for $24 \mathrm{~h}$ with $10 \mathrm{mM}$ L-glutamine compared with $1 \mathrm{mM}$ resulted in substantial changes in gene expression with 148 genes upregulated more than $1 \cdot 8$-fold, and 18 downregulated more than $1 \cdot 8$-fold, including many genes involved in cellular signaling, metabolism, gene regulation, and the insulin-secretory response. Subsequent functional experiments confirmed that L-glutamine increased the activity of the
\end{abstract}

$\mathrm{Ca}^{2+}$ regulated phosphatase calcineurin and the transcription factor Pdx1. Additionally, we demonstrated that $\beta$-cell-derived L-glutamate was released into the extracellular medium at high rates. As calcineurin is a regulator of the glutamate $N$-methyl-Daspartate (NMDA) receptor activity, we investigated the action of NMDA on nutrient-induced insulin secretion, and demonstrated suppressed insulin release. These observations indicate important long-term effects of L-glutamine in regulating $\beta$-cell gene expression, signaling, and secretory function.

Journal of Endocrinology (2006) 190, 719-727

\section{Introduction}

L-Glutamine circulates at the highest concentration of any amino acid (approximately $0.7 \mathrm{mmol} / 1$ in the human) and its metabolism is essential to the function of a large number of cells and tissues (reviewed in Newsholme et al. 2003). It has additionally been shown directly or indirectly to influence gene expression in specific target cells (Curi et al. 2005). It is readily metabolized in islets and $\beta$-cell lines, such as BRINBD11 (Malaisse et al. 1982a, 1982b, Rasschaert et al. 1996a, 1996b). Additionally, L-glutamate, which is derived intracellularly from L-glutamine, has been suggested to be a key messenger in the amplifying pathway of glucose-induced insulin release (Maechler \& Wollheim 1999, Wollheim 2000) although others have questioned the insulinotropic action of L-glutamate (Bertrand et al. 2002). It may additionally enter the $\gamma$-glutamyl cycle to produce glutathione (Brennan et al. 2003), which can enhance islet cell viability and insulin secretion (Ammon et al. 1980, Avila et al. 2003, 2005). However, acutely L-glutamine alone weakly stimulates insulin secretion (approximately 0.7 increased to $1.0 \mathrm{ng} / 10^{6}$ cells per $20 \mathrm{~min}$ in BRIN-BD11 cells, when it was increased from 0 to $10 \mathrm{mmol} / 1$ in the presence of $1.1 \mathrm{mmol} / 1$ glucose (McClenaghan et al. 1996)) and several papers question the proposed link between L-glutamate production and enhanced rates of exocytosis (MacDonald \& Fahien 2000, Bertrand et al.
2002). The question, therefore, arises as to the functional role of $\mathrm{L}$-glutamine in the $\beta$-cell.

L-Glutamine may be transported into the cell by a number of potential transport mechanisms (Prentki \& Renold 1983, Brennan et al. 2003) and is rapidly converted into L-glutamate. Glutamate dehydrogenase (GDH) activity, as measured in vitro, is high in pancreatic $\beta$-cells (Sener et al. 2001) and in $\beta$-cell lines, such as BRIN-BD11 (Rasschaert et al. 1996a, 1996b). However, the activity of the enzyme is tightly regulated in vivo by negative and positive effectors, such as GTP, ADP, and leucine. In the presence of leucine or its non-metabolizable analog, $\mathrm{BCH}$, L-glutamine potently enhances insulin secretion (Malaisse et al. 1982b, Gao et al. 1999). Leucine-activated GDH is considered to enhance L-glutamate oxidation and increase ATP production by providing the tricarboxylic acid (TCA) cycle with substrate (2-oxoglutarate), which will result in closure of plasma membrane $\mathrm{K}_{\mathrm{ATP}}^{+}$channels and stimulate insulin secretion. In support of this hypothesis, it is known that patients with rare mutations in the inhibitory GTP-binding allosteric site on GDH display elevated levels of insulin secretion, resulting in hypoglycemia (Stanley et al. 1998, 2000, MacMullen et al. 2001).

A recent study has shown that unregulated overexpression of GDH in MIN6 cells enabled glutamine alone to stimulate insulin secretion (Tanizawa et al. 2002). In contrast, glucose has been shown to inhibit the pathway of glutaminolysis 
(partial L-glutamine metabolism and oxidation) via inhibition of GDH (Gao et al. 1999).

We have previously presented ${ }^{13} \mathrm{C}$ NMR data, which provided novel evidence for substantial intracellular pancreatic $\beta$-cell metabolism of $\mathrm{L}$-glutamine resulting in formation of L-glutamate, L-aspartate, and glutathione (Brennan et al. 2003). We proposed that L-glutamate production is important to the $\beta$-cell as an intermediate of the $\gamma$-glutamyl cycle, which regulates cellular glutathione concentration.

Here, we report that chronic ( $24 \mathrm{~h}$ ) exposure to L-glutamine weakly stimulated insulin secretion (by 30\%), but induced significant changes in transcription factor, signal transduction, and metabolic enzyme gene expression. We have used $10 \mathrm{mM}$ L-glutamine in the work reported in this paper, so as to saturate L-glutamine transport and allow comparison of our results with previously published studies, which utilized $10 \mathrm{mM}$ L-glutamine to assess the effect on insulin secretion and $\beta$-cell function (Malaisse et al. 1982b, McClenaghan et al. 1996, Rasschaert et al. 1996a, 1996b, Brennan et al. 2003).

\section{Materials and Methods}

\section{Culture of BRIN-BD11 pancreatic $\beta$-cells}

Clonal insulin-secreting BRIN-BD11 cells were maintained in RPMI-1640 tissue culture medium (sigma) supplemented with $10 \%(\mathrm{v} / \mathrm{v})$ fetal calf serum, $0 \cdot 1 \%$ antibiotics $(100 \mathrm{U} / \mathrm{ml}$ penicillin and $0.1 \mathrm{mg} / \mathrm{ml}$ streptomycin) and $11.1 \mathrm{mmol} / 1$ D-glucose $(\mathrm{pH} 7 \cdot 4)$. The origin and characteristics of BRINBD11 cells are described elsewhere (McClenaghan et al. 1996). The cells were maintained at $37^{\circ} \mathrm{C}$ in a humidified atmosphere of $5 \% \mathrm{CO}_{2}$ and $95 \%$ air using a Forma Scientific incubator (Biosciences, Dublin, Ireland). The cells were cultured in 50$70 \mathrm{ml}$ tissue culture medium in T175 sterile tissue culture flasks. Cells were subsequently seeded into six-well plates $\left(1.5 \times 10^{6}\right.$ cells/well $)$ and allowed to adhere overnight. Cells were then washed with PBS after which fresh medium, containing $11 \cdot 1 \mathrm{mM}$ D-glucose and varying concentrations of L-glutamine $(0,1,2$, and $10 \mathrm{mM})$ was added. After $24 \mathrm{~h}$ incubation, an aliquot of the media was removed and centrifuged at $200 \mathrm{~g}$ for $5 \mathrm{~min}$ and used for quantitation of metabolites (L-glutamate, $\mathrm{NH}_{4}^{+}$, insulin, and urea).

\section{Enzymatic determination of metabolites}

Urea and $\mathrm{NH}_{4}^{+}$concentrations in the culture media were measured using an urease/GDH-based diagnostic kit (Fannin Healthcare, Dublin, Ireland). L-Glutamate concentration in the culture media was measured using a GDH-based diagnostic kit (Roche Diagnostics). Nitric oxide (NO) concentrations in the culture media were determined using the Griess Reagent System (Promega Medical Supply Co.). The rate of nitrite production was expressed as micromolar per milligram protein per $24 \mathrm{~h}$.

\section{Cellular glutamate determination}

BRIN-BD11 cells were cultured as above in six-well plates in the presence of either 1 or $10 \mathrm{mM}$ L-glutamine. After a $24 \mathrm{~h}$ incubation, cells were extracted with $6 \%$ perchloric acid and debris was removed from the wells using a cell scraper. After centrifugation, the supernatant was neutralized with $\mathrm{KOH}$ and the cellular L-glutamate concentration was quantified as described above. It is hydrolyzed to L-glutamate spontaneously at $37^{\circ} \mathrm{C}$ at a rate of approximately $5 \% / 24$ h over a concentration range of 1-20 $\mathrm{mM}$. This spontaneous rate of hydrolysis was taken into account when calculating rates of glutamate or $\mathrm{NH}_{4}^{+}$ production.

\section{Total glutathione assay}

Total glutathione was quantified in a microtiter plate according to the technique of Baker et al. (1990) using the method originally described by Tietze (1969). Cell lysate or reduced glutathione standards $(0-500 \mathrm{pmol}$ of $\mathrm{GSx} / 10 \mu \mathrm{l})$ was transferred into a microtiter plate and diluted with water. After addition of reaction mixture $(0 \cdot 1 \mathrm{M}$ sodium phosphate buffer ( $\mathrm{pH} 7.5)$ containing $1 \mathrm{mM}$ EDTA, $0.3 \mathrm{mM}$ dithionitrobenzoic acid, $0.4 \mathrm{mM} \mathrm{NADPH}$, and $1 \mathrm{U} / \mathrm{ml}$ glutathione reductase), the increase in absorbance at $405 \mathrm{~nm}$ was detected at $15 \mathrm{~s}$ intervals over a range of $2.5 \mathrm{~min}$ using a microtiter plate reader. Glutathione contents were evaluated using a calibration curve.

\section{Microarray analysis}

BRIN-BD11 cells were cultured as above in six-well plates in the presence of either $1 \mathrm{mM}$ (control) or $10 \mathrm{mM}$ L-glutamine. After $24 \mathrm{~h}$ incubation, total RNA was isolated using RNeasy columns from control samples (1 mM L-glutamine) and high glutamine samples (10 mM L-glutamine cells) in triplicate. RNA samples were prepared for microarray analysis using a protocol provided by Affymetrix (High Wycombe, UK). In summary, first and second strand cDNA synthesis was performed using the SuperScript Choice system using a HPLC purified T7-oligo (dT) primer. The double stranded cDNA was cleaned using the GeneChip Sample Cleanup Module (Affymetrix). Biotin labeled cRNA was then prepared using the Enzo RNA transcript kit (Enzo Life Sciences Inc., Farmingdale, NY, USA). The biotin labeled cRNA was cleaned using the GeneChip Sample Cleanup Module and fragmented at $94{ }^{\circ} \mathrm{C}$ for $35 \mathrm{~min}$, prior to hybridization with Affymetrix rat genome $230 \mathrm{~A}$ arrays. The probe arrays were incubated for $16 \mathrm{~h}$ at $40^{\circ} \mathrm{C}$. Probe sets were visualized on the Affymetrix GeneArray 2500 scanner and quantified for intensity using Microarray Suite version 5.1. Further data analysis was performed using GeneSpring version 6.1. Statistical analysis is included in the GeneSpring software (Affymetrix), so that only reproducible levels in gene expression (between triplicate samples) are included in the resulting 
Supplementary data Table 1 . To improve the robustness of the changes, genes were considered differentially expressed if they were present in 1 and $10 \mathrm{mM}$ glutamine-treated cells. Some $\beta$-cell-specific genes that were upregulated at least $1 \cdot 8$-fold were chosen for further analysis (see below).

\section{Real-time PCR}

We selected seven genes that had shown more than $1 \cdot 8$-fold change in expression for further study by reverse transcriptase (RT)-PCR in a separate experiment. BRIN-BD11 cells were cultured as above in six-well plates in the presence of either 1 or $10 \mathrm{mM}$ L-glutamine. After $24 \mathrm{~h}$ incubation, total RNA from three biological replicates of each treatment was isolated using the QIAGEN RNeasy Mini Kit (Qiagen Ltd., West Sussex, UK). Target mRNA was quantified using an ABI PRISM 7700 Sequence Detection System (Applied Biosystems Foster City, CA, USA). Primers and probes (Table 3) were designed using ABI PRISM Primer Express software v.1.5 (Applied Biosystems). Primers were purchased from Sigma-Genosys and probes from Applied Biosystems. The probes were labeled with a $5^{\prime}$-reporter dye (FAM, 6-carboxyfluorescein) and a $3^{\prime}$-quencher dye (TAMRA, 6-carboxytetramethylrhodamine). RT-PCR were carried out in a microamp optical 96-well plate in a total volume of $25 \mu \mathrm{l} /$ well, consisting of TaqMan 1-step RT-PCR master mix Reagent kit (Applied Biosystems), 20 ng total RNA, $0 \cdot 25 \mathrm{U} / \mu \mathrm{l}$ Multiscribe, and concentrations of primers and probes ranging from 100 to $500 \mathrm{nmol} / \mathrm{l}$. Reverse transcription was performed for $30 \mathrm{~min}$ at $48{ }^{\circ} \mathrm{C}$, AmpliTaq gold activation for $10 \mathrm{~min}$ at $95^{\circ} \mathrm{C}$, followed by 40 PCR cycles of denaturation at $95^{\circ} \mathrm{C}$ for $15 \mathrm{~s}$ and annealing/extension at $60{ }^{\circ} \mathrm{C}$ for $1 \mathrm{~min}$. Reactions were carried out in triplicate and data were analyzed by the ABI PRISM 7700 Sequence Detection System software (Applied Biosystems) using a standard curve to quantify the mRNA. Standard curves were produced for each set of primers and probes using 5$80 \mathrm{ng}$ total RNA per reaction. Results were normalized on the basis of $18 \mathrm{~S}$ rRNA quantification. The genes analyzed by real time PCR were: calcineurin (catalytic subunit, $P p p c b 3$ and regulatory subunit, Ppp3r1), pancreatic and duodenal homeobox gene 1 (PDX1), acetyl CoA carboxylase (Acac), potassium inwardly rectifying channel (Kcnj6), potassium channel (Kcnk2) and glutamate receptor, ionotropic (Grin1a).

\section{Western blot analysis}

Twenty micrograms protein extracts were prepared using NE-PER Nuclear and Cytoplasmic Extraction Reagents (Pierce, Rockfort, IL, USA). Samples were subsequently subjected to 6\% SDS-PAGE and electrophoretically transferred onto a nitrocellulose sheet. The sheet was blocked in $5 \%$ milk protein and incubated with polyclonal anti acetyl CoA carboxylase (Santa Cruz Biotechnology Inc., Santa Cruz, CA, USA). The blots were washed and probed with horseradish peroxidase and visualized with Supersignal West Pico chemiluminescent substrate (Pierce).

\section{Calcineurin enzymatic activity assay}

Calcineurin activity assays were performed on BRIN-BD11 cell lysates using a colorimetric calcineurin activity assay kit as described in the manufacturer's protocol (Calbiochem, kit no. 2007007; Merk). Reactions were terminated after $30 \mathrm{~min}$, and absorption was read on an u.v. spectroscope at $660 \mathrm{~nm}$. The activity was corrected for differences in protein concentration between samples.

\section{Electrophoretic mobility shift assay (EMSA)}

BRIN-BD11 cells were cultured as above in six-well plates in the presence of either 1 or $10 \mathrm{mM}$ L-glutamine. After $24 \mathrm{~h}$ incubation, nuclear protein extract was prepared using NE-PER reagent. A LightShift Chemiluminescent EMSA Kit (Pierce) was used to detect DNA-protein interactions. A double-stranded oligonucleotide corresponding to the FARFLAT element of the rat insulin 1 promoter was biotin endlabeled and incubated with a nuclear extract. This reaction was then subjected to gel electrophoresis on a native polyacrylamide gel and transferred to a nylon membrane. The biotin end-labeled DNA was detected using the streptavidin-horseradish peroxidase conjugate and the chemiluminescent substrate.

Insulin secretion (in the presence of glutamate receptor agonists and antagonists)

BRIN-BD11 cells were cultured in 24-well plates for $24 \mathrm{~h}$ in RPMI-1640 medium containing $11 \cdot 1 \mathrm{mM}$ D-glucose. After $40 \mathrm{~min}$ pre-incubation in Krebs ringer bicarbonate buffer (KRB; $\mathrm{NaCl} 115 \mathrm{mM}, \mathrm{KCL} 4.7 \mathrm{mM}, \mathrm{CaCl}_{2} \cdot 6 \mathrm{H}_{2} \mathrm{O}$ $1.28 \mathrm{mM}, \quad \mathrm{KH}_{2} \mathrm{PO}_{4} 1 \cdot 2 \mathrm{mM}, \mathrm{MgSO}_{4} .7 \mathrm{H}_{2} \mathrm{O} 1.2 \mathrm{mM}$, $\mathrm{NaHCO}_{3}, 10 \mathrm{mM}$, BSA $0 \cdot 1 \%, \mathrm{pH} 7 \cdot 4$ ) with $1.1 \mathrm{mM}$ glucose at $37^{\circ} \mathrm{C}$, the BRIN-BD11 cells were incubated in $\mathrm{KRB}$ containing $16.7 \mathrm{mM}$ D-glucose in the presence or absence of $10 \mathrm{mM}$ L-alanine for $20 \mathrm{~min}$ in order to stimulate the first phase of insulin secretion. The combination of glucose and L-alanine is required to stimulate robust and reproducible levels of insulin secretion (Brennan et al. 2002, Dixon et al. 2003). Various glutamate receptor agonists (AP4, L-CCG1, (S)-3, 5-dihydroxy-phenylglycine (DHPG), and NMDA; Sigma) were included in this 20-min incubation period, after which, an aliquot was removed from each well and analyzed for insulin content using the Mercodia Ultrasensitive Rat Insulin ELISA kit (Uppsala, Sweden).

\section{Chronic (24h) insulin secretion}

BRIN-BD11 cells were seeded in 24-well plates $\left(1 \times 10^{5}\right.$ cells/well) in RPMI-1640 medium containing $11 \cdot 1 \mathrm{mM}$ D-glucose in the presence of either 1 or $10 \mathrm{mM}$ L-glutamine. 
After $24 \mathrm{~h}$ incubation, an aliquot of the media was removed and centrifuged at $200 \mathrm{~g}$ for $5 \mathrm{~min}$ and analyzed for insulin content using the Mercodia Ultrasensitive Rat Insulin ELISA kit.

\section{Protein determination}

Cellular protein was determined using a bianchoninic acid protein assay kit (Pierce; kit no. 23225), which utilizes a modification of the biuret reaction.

\section{Statistical analysis}

The results are presented as means \pm s.D. Groups of data were compared using a Student's unpaired $t$-test or ANOVA where appropriate. Differences were considered significant at a $P$ value $<0 \cdot 05$.

\section{Results}

L-Glutamate, $\mathrm{NH}_{4}^{+}$, urea and nitrite production in BRIN-BD11 $\beta$-cells

No previous study has as yet reported the release and extracellular production rates of L-glutamate from pancreatic $\beta$-cells. Incubation of BRIN-BD11 cells in the presence of $10 \mathrm{mM}$ L-glutamine significantly $(P<0 \cdot 05)$ increased the extracellular glutamate concentration from $1 \cdot 26 \mu \mathrm{mol} / 10^{6}$ cells per $24 \mathrm{~h}(0 \mathrm{mM}$ L-glutamine $)$ to $2 \cdot 59 \mu \mathrm{mol} / 10^{6}$ cells per $24 \mathrm{~h}$ (Table 1). Extracellular $\mathrm{NH}_{4}^{+}$production dramatically increased on addition of extracellular L-glutamine, resulting in an up to eightfold $(P<0 \cdot 02)$ increase over basal $(0 \mathrm{mM}$ glutamine $)$ production rates (Table 1 ). However, addition of L-glutamine to the culture medium did not alter urea production rates over 24 h. Nitrite concentrations in the culture medium were not significantly altered by addition of extracellular L-glutamine (Table 1). The intracellular glutamate concentration was also significantly increased on raising the extracellular glutamine concentration from 1 to $10 \mathrm{mM}\left(15 \cdot 2-20 \cdot 9 \mathrm{nmol} / 10^{6}\right.$ cells per $24 \mathrm{~h})$, as was the intracellular glutathione concentration $(5 \cdot 1-$ $6 \cdot 6 \mathrm{nmol} / 10^{6}$ per $24 \mathrm{~h}$; Table 2 ).
Effect of chronic exposure to L-glutamine on BRIN-BD11 cell insulin secretion

We have previously reported that acute addition $(20 \mathrm{~min}$ ) of L-glutamine alone weakly stimulated insulin secretion (McClenaghan et al. 1996). In this study, the $24 \mathrm{~h}$ secretion rate of insulin by BRIN-BD11 $\beta$-cells exposed to L-glutamine was determined. Increasing the extracellular L-glutamine concentration from 1 to $10 \mathrm{mM}$ resulted in a $30 \%$ increase in the insulin secretion rate $(P<0 \cdot 05$; Table 1$)$.

\section{Microarray analysis}

Analysis performed using the Affymetrix rat genome 230A microarray revealed that the expression of a total of 148 genes were increased $1 \cdot 8$-fold or greater after $24 \mathrm{~h}$ culture of BRIN-BD11 $\beta$-cells in the presence of $10 \mathrm{mM}$ L-glutamine compared with culture in the presence of $1 \mathrm{mM}$ L-glutamine. Additionally, 18 genes were downregulated by $1 \cdot 8$-fold or more by $10 \mathrm{mM}$ L-glutamine. These genes are grouped according to molecular function in the Supplementary data Table 1. The largest group of genes up/downregulated by L-glutamine was functionally classified as signal transduction. This group could further be subdivided into genes involved in phosphorylation/dephosphorylation, G-protein coupling and $\mathrm{Ca}^{2+}$ binding. Both the regulatory and catalytic subunits of the calcium-binding protein, calcineurin were upregulated approximately $6-$ and $1 \cdot 9$-fold respectively. Interestingly, the homeodomain transcription factor $P D X 1$ was upregulated more than fivefold by L-glutamine. PDX1 plays a key role in pancreatic development and $\beta$-cell function. Genes altered by L-glutamine addition were grouped as follows: signal transduction (16\%), growth/gene regulation (16\%), metabolism (10\%), structural (7\%) channels/receptors (6\%), apoptosis/inflammatory response (4\%), transport (2\%), miscellaneous (13\%), and ESTs (26\%).

\section{Real-time PCR analysis of glutamine-regulated genes}

Selected targets, as described below, were confirmed using real time PCR. The sequences of the primer sets used in real

Table 1 Metabolite production and insulin secretion in BRIN-BD11 cells after a $24 \mathrm{~h}$ incubation in the presence of various concentrations of L-glutamine

\begin{tabular}{|c|c|c|c|c|c|}
\hline & $\begin{array}{l}\text { Glutamate } \\
\text { production } \\
\text { (extracellular) }\end{array}$ & $\mathrm{NH}_{4}^{+}$production & Urea production & Insulin secretion & Nitrite production \\
\hline \multicolumn{6}{|c|}{$\begin{array}{l}\text { Glutamine } \\
\text { conc. }(\mathrm{mM})\end{array}$} \\
\hline 0 & $1 \cdot 26 \pm 0 \cdot 43$ & $0 \cdot 63 \pm 0 \cdot 21$ & - & - & - \\
\hline 1 & $1 \cdot 62 \pm 0 \cdot 29$ & $1 \cdot 74 \pm 0 \cdot 37$ & $0 \cdot 814 \pm 0 \cdot 19$ & $233 \cdot 84 \pm 24 \cdot 87$ & $0 \cdot 15 \pm 0 \cdot 04$ \\
\hline 2 & $1 \cdot 95 \pm 0 \cdot 28$ & $3 \cdot 01 \pm 0 \cdot 34^{*}$ & $0 \cdot 801 \pm 0 \cdot 23$ & - & - \\
\hline
\end{tabular}

Values are expressed as $\mu \mathrm{mol} / 10^{6}$ cells per $24 \mathrm{~h}$ (except for insulin secretion which is expressed in ng/10 ${ }^{6}$ cells per $24 \mathrm{~h}$ ) \pm s.D. for five to six

independent experiments. Metabolite concentrations and insulin secretion was determined as described in Materials and Methods. Statistically significant differences in production (ANOVA) are indicated by $* P<0.05$ compared with consumption or production or secretion in the presence of $1 \mathrm{mM}$ L-glutamine. 
Table 2 Cellular L-glutamate and total glutathione levels in BRINBD11 cells after $24 \mathrm{~h}$ incubation in the presence of 1 or $10 \mathrm{mM}$ extracellular L-glutamine

\begin{tabular}{|c|c|c|}
\hline \multirow[b]{2}{*}{ Glutamine conc. $(\mathrm{mM})$} & Cellular glutamate & Total glutathion \\
\hline & & \\
\hline 1 & $15 \cdot 28 \pm 1 \cdot 98$ & $5 \cdot 09 \pm 0 \cdot 62$ \\
\hline 10 & $20 \cdot 89 \pm 3 \cdot 21^{*}$ & $6 \cdot 61 \pm 0.56^{*}$ \\
\hline
\end{tabular}

Values are expressed as nmol/10 $10^{6}$ cells per $24 \mathrm{~h} \pm$ s.D. for five to six independent experiments. Cellular glutamate and total glutathione were determined as described in Materials and Methods. ${ }^{*} P<0 \cdot 05$ compared with intracellular levels after incubation in the presence of $1 \mathrm{mM}$ glutamine.

time PCR analysis are described in Table 3. The levels of the regulatory and catalytic subunits of calcineurin, the transcription factor PDX1, the metabolic enzyme acetyl CoA carboxylase, the KIR subunit of the $\mathrm{K}_{\mathrm{ATP}}^{+}$channel, and the ionotropic L-glutamate receptor Grinl1a were chosen for independent verification as they are involved in signal transduction, insulin gene expression, metabolism, and regulation of insulin secretion in pancreatic $\beta$-cells. As shown in Fig. 1, the upregulation of the latter genes determined by microarray analysis was confirmed using real time PCR. Overall, there was very good agreement between increases in gene expression determined by the two methods.

Western blot analysis of acetyl co $A$ carboxylase expression and calcineurin activity measurement in the presence of 1 or $10 \mathrm{mM}$ L-glutamine

Western blot analysis of acetyl CoA carboxylase expression clearly demonstrated that increasing the extracellular L-glutamine concentration from 1 to $10 \mathrm{mM}$ over $24 \mathrm{~h}$ resulted in an increase of approximately twofold in acetyl CoA carboxylase protein expression (Fig. 2A). Following real-time PCR confirmation that L-glutamine increased the mRNA expression of both the catalytic and regulatory subunits of calcineurin, the calcineurin-specific phosphatase activity in BRIN-BD11 $\beta$-cells was determined. Calcineurin activity increased almost twofold $(P<0 \cdot 05)$, when Lglutamine was increased from 1 to $10 \mathrm{mM}$ over $24 \mathrm{~h}$ (Fig. 2B).
Electrophoretic mobility shift assay

Following real time PCR confirmation of significant glutamine-dependent upregulation of PDX1 mRNA, the specific DNA:protein interactions were investigated further via EMSA. Increasing the L-glutamine concentration from 1 to $10 \mathrm{mM}$ resulted in increased binding of the PDX1 protein to its specific binding site, the FAR-FLAT element of the rat insulin 1 promoter (Fig. 3).

\section{Effects of NMDA glutamate receptor agonists and specific metabotropic glutamate receptor ( $m G l u R)$ agonists on nutrient-induced insulin secretion}

RINm5F pancreatic $\beta$-cells (parental cell line of the BRINBD11) have been shown to express NMDA receptors and mGluRs (Molnar et al. 1995, Brice et al. 2002). In a previous study, L-alanine was shown to be a potent amino acid insulin secretagog in the BRIN-BD11 cell line (McClenaghan et al. 1996). In this study, alanine-induced insulin secretion in the presence of various glutamate receptor agonists was determined. One hundred micromolars of NMDA significantly reduced L-alanine-induced insulin secretion $(P<0 \cdot 05)$ in the presence of either 1.1 or $16.7 \mathrm{mM}$ D-glucose (Fig. 4). The group III specific mGluR agonist L-AP4 also significantly $(P<0 \cdot 05)$ reduced L-alanineinduced insulin secretion in the presence of either $1 \cdot 1$ or $16.7 \mathrm{mM}$ D-glucose (Fig. 4). However, Groups I and II specific mGluR agonists DHPG and L-CCG1 respectively had no effect on insulin secretion under any of the conditions tested (Fig. 4).

\section{Discussion}

Amino acids may exert chronic influences on cell function via a number of mechanisms (Haussinger 1996, Averous et al. 2003, Curi et al. 2005). In the work reported here, L-glutamine increased the $24 \mathrm{~h}$ insulin secretion rate of BRIN-BD11 $\beta$-cell line by 30\%. This was associated with an upregulation of 148 genes of at least $1 \cdot 8$-fold and similarly, downregulation of 18 genes. Notably, BRIN-BD11 cells (in common with all transformed cell lines) required exposure to L-glutamine at a minimum concentration of $1 \mathrm{mM}$, to avoid

Table 3 Sequences of primer sets used in real time PCR analysis

\begin{tabular}{|c|c|c|c|}
\hline & Genbank accession no. & Forward primer $\left(5^{\prime}-3^{\prime}\right)$ & Reverse primer $\left(5^{\prime}-3^{\prime}\right)$ \\
\hline \multicolumn{4}{|c|}{ Gene name } \\
\hline Acac & NM_022193 & CGGCTGTGGAAATTGCG & GAGGCGGATGGGAATCG \\
\hline$P d x 1$ & NM_022852 & TTCCCGTGGATGAAATCCA & TCCGGTTCTGCTGCGTATG \\
\hline Рpp3r1 & NM_017309 & TGTCAAAGGCCGATAAGGAACAG & TTGAGGTTCGCTTTCCGTATCT \\
\hline Рpp3cb & NM_017042 & CCCACAGGGATGTTGCCTAGT & AACTGTGGCACTTTGCAAGGT \\
\hline Kcnk2 & NM_172041 & CTACAAGCCCGTTGTGTGGTT & GCTCAGAACAGCCGCAAAGT \\
\hline Kcnj6 & NM_013192 & AATGGTGGAAGCCACAGGAA & CCGGTAACCCCACAGGCTCT \\
\hline Grin/1a & NM_183402 & TTACAGCAGCACGCCTTCTTC & GAGCCAGCGACTCTTCTATGGA \\
\hline
\end{tabular}




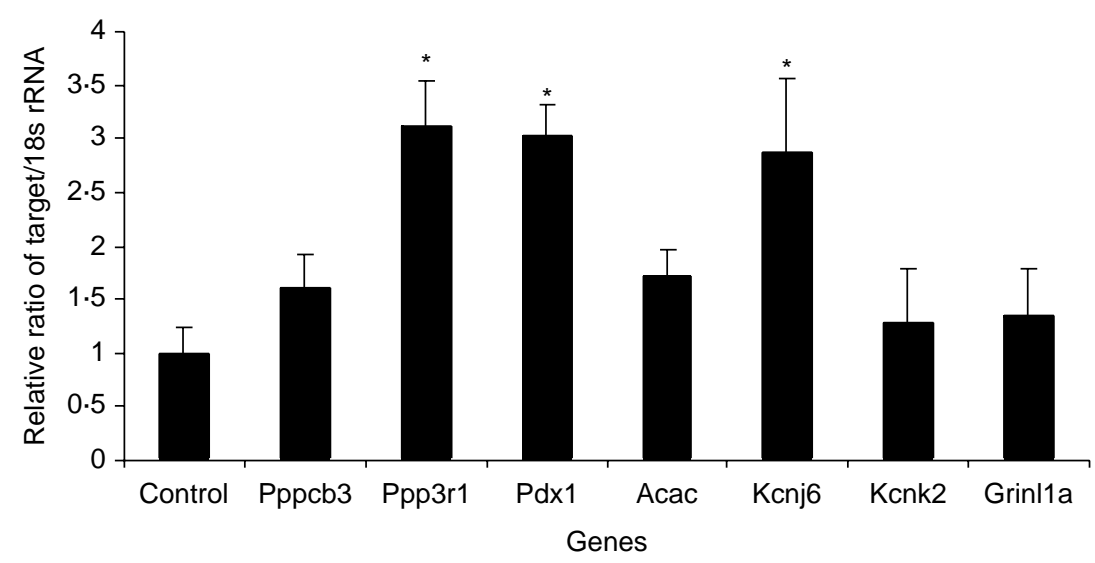

Figure 1 Real-time PCR analysis of L-glutamine-affected genes. Confirmation by real timePCR of seven genes that had shown more than $1 \cdot 8$-fold $10 \mathrm{mM} \mathrm{L-glutamine-induced} \mathrm{change}$ in expression by microarray analysis. BRIN-BD11 cells were cultured in the presence of either 1 or $10 \mathrm{mM}$ L-glutamine. After $24 \mathrm{~h}$ incubation, total RNA from three biological replicates of each treatment was isolated using the QIAGEN RNeasy Mini Kit. Target mRNA was quantified using an ABI PRISM 7700 Sequence Detection System (Applied Biosystems) as described in Materials and Methods. The data are presented as a percentage of the respective $1 \mathrm{mM}$ L-glutamine control which received an arbitrary value of 1 in each experiment. Values are means \pm s.D., $* P<0 \cdot 05$.

significant loss of viability during a chronic period of incubation.

Detailed microarray analysis revealed that the largest functional clusters of genes changed by $24 \mathrm{~h}$ exposure to L-glutamine were those involved in signal transduction, gene regulation, and metabolism (see Supplementary data Table 1). Not all the genes described in the Supplementary data Table 1 would be expected to be expressed in the $\beta$-cell (especially those listed in the 'Miscellaneous' or 'Signaling - Other' sections) but those selected for further analysis by real time PCR, Western blot, or activity measurement are normally expressed in $\beta$-cells. L-Glutamine is rapidly metabolized via glutaminase to L-glutamate and $\mathrm{NH}_{4}^{+}$(Brennan et al. 2003). However, the production rate of urea was not altered by L-glutamine, in contrast to the production rate of $\mathrm{NH}_{4}^{+}$. Urea production from pancreatic $\beta$-cells in culture has been previously reported by others (Webb et al. 2000, 2001) but the significance of this finding is not known. It may be related to the regulation of NO production (as inducible nitric oxide synthase will compete with arginase for available L-arginine, as described for the mouse macrophage and human monocyte (Murphy \& Newsholme 1998). We propose that the $\beta$-cell glutamate is converted to 2-oxoglutarate on activation of $\mathrm{GDH}$, and then to malate via reactions of the TCA cycle.
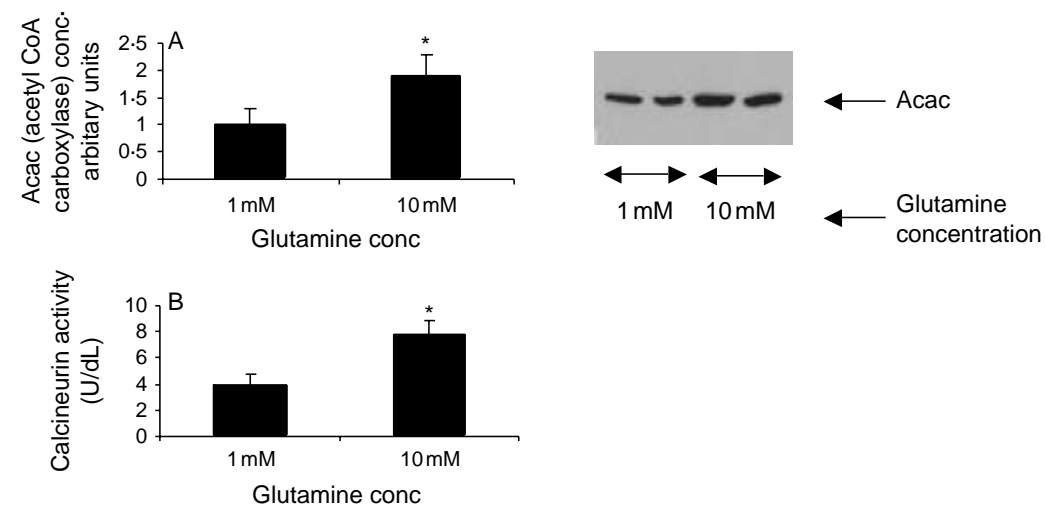

Figure 2 (A) Western blot analysis confirming L-glutamine induced upregulation of acetyl CoA carboxylase protein was performed as described in Materials and Methods. (B) Measurement of calcineurin activity in BRIN-BD11 cells after a $24 \mathrm{~h}$ incubation in the presence of 1 or $10 \mathrm{mM}$ L-glutamine. Calcineurin activity assays were performed on BRIN-BD11 cell lysates using a colorimetric calcineurin activity assay kit, as described in the manufacturer's protocol (Calbiochem). 


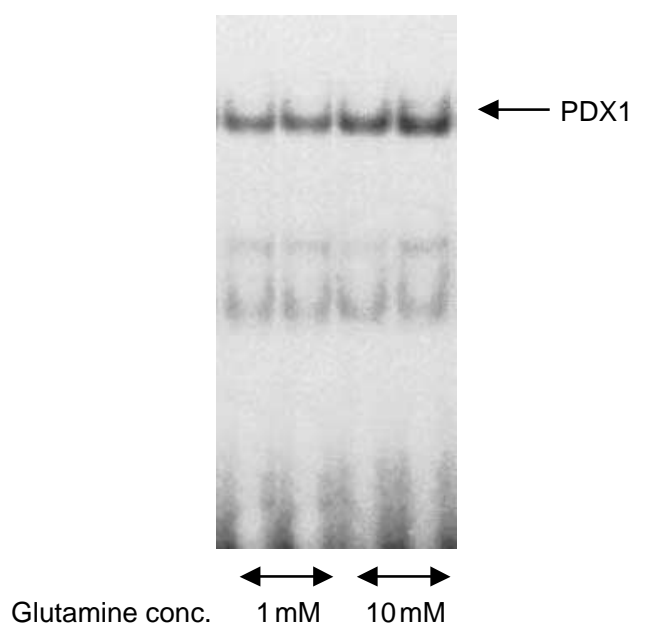

Figure 3 An electrophoretic mobility shift assay was used to confirm an increase in PDX1 transcription factor-binding activity after incubation in $10 \mathrm{mM}$ L-glutamine compared to $1 \mathrm{mM}$ L-glutamine, as described in Materials and Methods.

Subsequently, malate may be converted to pyruvate and then citrate (Newsholme et al. 2003). Citrate may then leave the mitochondrial matrix and be converted to acetyl-CoA and oxaloacetate in the cytosol. Acetyl-CoA can then be converted to malonyl CoA by acetyl-CoA carboxylase (which we report here to be upregulated by L-glutamine at the mRNA and protein level) and so enter the pathway of fatty acid synthesis. Fatty acid synthesis appears to be essential for optimal stimulation of insulin secretion in the $\beta$-cell
(Haber et al. 2003) due to generation of lipid-derived signaling molecules. Long chain acyl-CoAs, glutamate, glutathione, or reactive oxygen species could activate a number of kinases, such as JNK, p38 MAPK, or protein kinase C (Yaney \& Corkey 2003). Glutamate may additionally enter the $\gamma$-glutamyl cycle as previously described (Brennan et al. 2003) and so contribute to $\beta$-cell glutathione production and antioxidant defenses. Thus, the mechanisms by which L-glutamine metabolism influences $\beta$-cell signal transduction and gene expression are probably related to generation of key amino acid stimulus secretion coupling factors (L-glutamate), generation of lipid metabolites (long chain acyl-CoAs), and by ensuring adequate levels of cellular glutathione, which may be important for optimizing mitochondrial function, as previously described (Brennan et al. 2003).

One important gene significantly upregulated by L-glutamine was $p d x 1$, a factor essential for pancreatic $\beta$-cell differentiation and function. Studies of rat islets following adenoviral transfection with a dominant-negative $p d x 1$ gene demonstrated reduced glucose-stimulated insulin secretion, decreased islet ATP content, and reduced expression of a number of mitochondrial genes required for ATP generation (Gauthier et al. 2004). The significant glutamine-dependent upregulation of PDX1 mRNA and increased PDX-1 transcription binding assessed by EMSA observed in this study is a novel finding and deserves further evaluation. This finding may have relevance for the optimal in vitro differentiation of pancreas-derived and possibly embryonic stem cells towards $\beta$-cell phenotype.

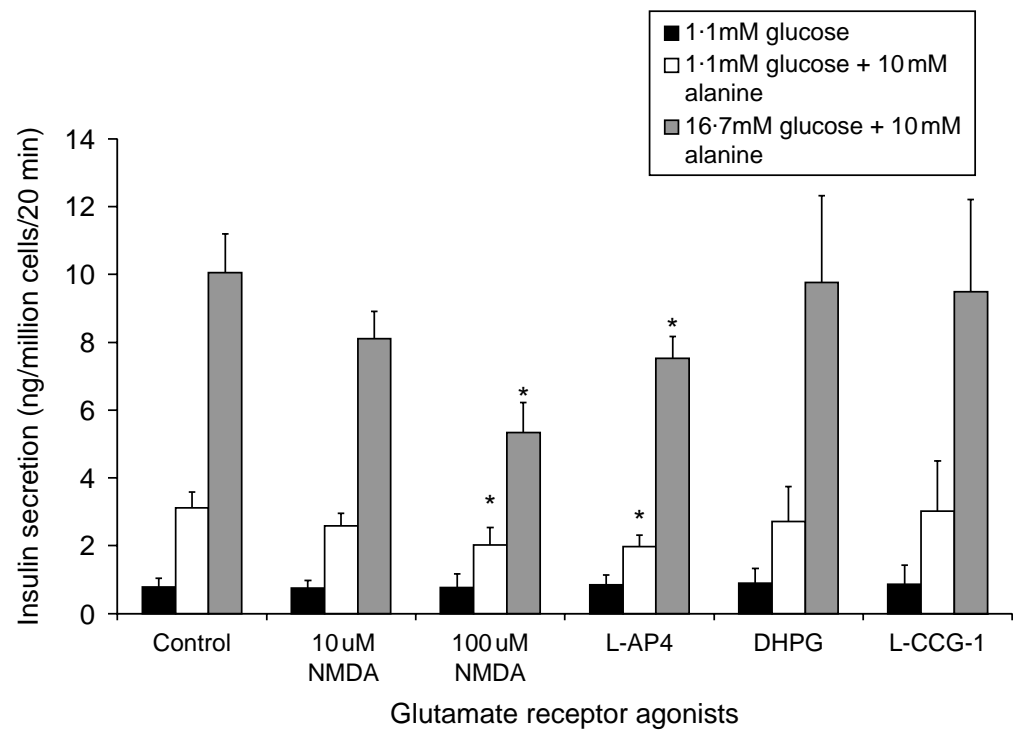

Figure 4 Basal, L-alanine, or glucose plus L-alanine-induced insulin secretion in the presence of specific metabotropic glutamate receptor (mGluR) agonists (L-AP4, DHPG, and L-CCG1) or NMDA. Effects of glutamate receptor agonists were determined as described in Materials and Methods. Values are means \pm s.D. Statistically significant differences (ANOVA) are indicated by $* P<0.05$ compared to appropriate control (absence of receptor agonist). 
L-Glutamine strongly upregulated both the calcineurin catalytic and regulatory subunit mRNA expression in BRINBD11 cells. Calcineurin, or protein phosphatase $2 \mathrm{~B}$, is a calcium-binding protein that has been shown to contribute to the mechanism of somatostatin-induced inhibition of exocytosis in mouse pancreatic $\beta$-cells (Renstrom et al. 1996). In addition, it is now appreciated that the cAMP response element-binding protein (CREB) transcription factor regulates specific pro-survival genes in the $\beta$-cell. CREB translocation to the nucleus is regulated by specific $\mathrm{Ca}^{2+}$-dependent dephosphorylation of TORC (transducers of regulated CREB) by calcineurin (Schuit et al. 2005). Indeed, a recent report has shown that the addition of $5 \mathrm{mM}$ L-glutamine to the isolation medium applied through the main pancreatic duct, improved yield, survival, and function of human islets that were destined for transplantation (Avila et al. 2005). Calcineurin has also been reported to modulate NMDA receptor activity (Lieberman \& Mody 1994). NMDA-specific glutamate receptors are expressed in pancreatic $\beta$-cells (Molnar et al. 1995) but their function has not been clearly defined. In the present study, upregulation of the calcineurin gene resulted in increased calcineurin-specific phosphatase activity, which in vivo will lead to NMDA receptor inactivation. NMDA receptors normally stimulate $\mathrm{Na}^{+}$and $\mathrm{Ca}^{2+}$ influx (Dingledine et al. 1999), which would be expected to depolarize the cell membrane and promote insulin secretion. However, chronic receptor stimulation by L-glutamate (when released at high levels) may desensitize the $\beta$-cell to subsequent nutrient-stimulated insulin secretion. Calcineurin may reduce NMDA receptor-mediated desensitization.

We have uniquely reported here that $\mathrm{L}$-glutamate is released from the BRIN-BD11 $\beta$-cell into the extracellular medium. The quantity of glutamate released was large - indeed, based on the reported increase of extracellular and intracellular glutamate on increasing extracellular glutamine from 1 to $10 \mathrm{mM}$ (approximately $1 \mu \mathrm{mol} / 10^{6}$ cells per $24 \mathrm{~h}$ reported in Table 1, compared with approximately $5 \mathrm{nmol} / 10^{6}$ cells per $24 \mathrm{~h}$ reported in Table 2 respectively), then glutamate was released into the extracellular medium at a rate almost 200 -fold above the intracellular production rate. While we appreciate that the acute rate of glutamate release from the $\beta$-cell (i.e. $<1 \mathrm{~h}$ ) is probably low, chronic glutamate release may cause glutamate receptor activation and desensitization of the cell to further insulinotropic signals, representing a novel autocrine mechanism for regulation of $\beta$-cell function. Exogenously applied NMDA or the metabotropic glutamate receptor agonist L-AP4 significantly reduced acute L-alanine and glucose-induced insulin secretion. Although the present study has utilized acute periods of stimulation of insulin secretion to determine the effects of NMDA or L-AP4, we appreciate that chronic regulation of insulin secretion may be influenced in a different manner by glutamate receptordependent mechanisms. Interestingly, glutamine metabolism in the $\beta$-cell may therefore play multiple roles: (i) production of intracellular glutamate and glutathione, which acutely stimulate insulin secretion (Brennan et al. 2003), (ii) stimulation of acyl-CoA production, which would be important for the amplification of insulin secretion, (iii) chronic release of glutamate from the cell therefore inhibiting insulin secretion via interaction with ionotropic and metabotropic glutamate receptors, and (iv) upregulation of calcineurin expression and activity, which may impact on pro-survival gene expression and NMDA receptor-dependent ion fluxes.

In conclusion, we have demonstrated multiple roles for L-glutamine in the acute and chronic regulation of $\beta$-cell function. However, it should be noted that, like many other published studies, high concentrations of L-glutamine were used in vitro. Such an approach results in optimal glutamine transport into target cells and metabolism thus facilitating production of signaling molecules, which at lower concentrations, might not be detectable.

\section{Acknowledgements}

We thank the Health Research Board of Ireland for a Research Project Grant (RP62/2001), which supported this work. The authors declare that there is no conflict of interest that would prejudice the impartiality of this scientific work.

\section{References}

Ammon HPT, Grimm A, Lutz S, Wagner-Teschner D, Händel M \& Hagenloh I 1980 Islet glutathione and insulin release. Diabetes 830834.

Averous J, Bruhat A, Mordier S \& Fafournoux P 2003 Recent advances in the understanding of amino acid regulation of gene expression. Journal of Nutrition 133 2040S-2045S.

Avila JG, Tsujimura T, Oberholzer J, Churchill T, Salehi P, Shapiro AMJ \& Lakey JRT 2003 Improvement of pancreatic islet isolation outcomes using glutamine perfusion during isolation procedure. Cell Transplantation 12 877-881.

Avila J, Barbaro B, Gangemi A, Romagnoli T, Kuechle J, Hansen M, Shapiro J, Testa G, Sankary H, Benedetti E et al. 2005 Intraductal glutamine administration reduces oxidative injury during human pancreatic islet isolation. American Journal of Transplantation 5 2830-2837.

Baker MA, Cerniglia GJ \& Zaman A 1990 Microtiter plate assay for the Measurement of glutathione and glutathione disul in large numbers of biological samples. Annals of Biochemistry 190 360-365.

Bertrand G, Ishiyama N, Nenquin M, Ravier MA \& Henquin J-C 2002 The elevation of glutamate content and the amplification of insulin secretion in glucose-stimulated pancreatic islets are not causally related. Journal of Biological Chemistry 277 32883-32891.

Brennan L, Shine A, Hewage C, Malthouse JPG, Brindle K, McClenaghan N, Flatt PR \& Newsholme P 2002 A NMR based demonstration of substantial oxidative L-alanine metabolism and L-alanine enhanced glucose metabolism in a clonal pancreatic bete-cell line - metabolism of L-alanine is important to the regulation of insulin secretion. Diabetes 51 1714-1721.

Brennan L, Corless M, Hewage C, Malthouse JPG, McClenaghan NH, Flatt PR \& Newsholme P $2003{ }^{13}$ C NMR analysis reveals a link between L-glutamine metabolism, D-glucose metabolism and gammaglutamyl cycle activity in a clonal pancreatic beta-cell line. Diabetologia $\mathbf{4 6}$ 1512-1521. 
Brice NL, Varadi A, Ashcroft SJ \& Molnar E 2002 Metabotropic glutamate and $\mathrm{GABA}(\mathrm{B})$ receptors contribute to the modulation of glucosestimulated insulin secretion in pancreatic beta cells. Diabetologia 45 242-252.

Curi R, Lagranha CJ, Doi SQ, Sellitti F, Procopio J, Pithon-Curi TC, Corless M \& Newsholme P 2005 Molecular mechanisms of glutamine action. Journal of Cellular Physiology 204 392-401.

Dingledine R, Borges K, Bowie D \& Traynelis SF 1999 The glutamate receptor ion channels. Pharmacological Reviews 761.

Dixon G, Nolan J, McClenaghan NH, Flatt PR \& Newsholme P 2003 A comparative study of amino acid consumption by rat islet cells and the clonal beta-cell line BRIN-BD11 - the functional significance of L-alanine. Journal of Endocrinology 179 447-454.

Gao Z-Y, Li G, Najafi H, Wolf BA \& Matschinski FM 1999 Glucose regulation of glutaminolysis and its role in insulin secretion. Diabetes 48 1535-1542.

Gauthier BR, Brun T, Sarret EJ, Ishihara H, Schaad O, Descombes P \& Wollheim CB 2004 Oligonucleotide microarray analysis reveals PDX1 as an essential regulator of mitochondrial metabolism in rat islets. Journal of Biological Chemistry 279 31121-31130.

Haber EP, Ximenes HM, Procopio J, Carvalho CR, Curi R \& Carpinelli A 2003 Pleiotropic effects of fatty acids on pancreatic beta-cells. Journal of Cellular Physiology 194 1-12.

Haussinger D 1996 The role of cellular hydration in the regulation of cell function. Biochemical Journal 313 697-710.

Lieberman DN \& Mody I 1994 Regulation of NMDA channel function by endogenous $\mathrm{Ca}^{2+}$ dependent phosphatase. Nature 369 235-239.

MacDonald MJ \& Fahien LA 2000 Glutamate is not a messenger in insulin secretion. Biochemical Journal 275 34025-34027.

McClenaghan NH, Barnett CR, O’Harte FPM \& Flatt PR 1996 Mechanisms of amino acid-induced insulin secretion from the glucose-responsive BRIN-BD11 pancreatic $\beta$-cell line. Journal of Endocrinology 15 349-357.

MacMullen C, Fang J, Hsu BYL, Kelly A, De Lonlay-Debeney P, Saudubray J-M, Ganguly A, Smith TJ \& Stanley CA 2001 The hyperinsulinism/hyperammonemia syndrome in children with regulatory mutations in the inhibitory guanosine triphosphate binding domain of glutamate dehydrogenase. Journal of Clinical Endocrinology and Metabolism 86 1782-1787.

Maechler P \& Wollheim CB 1999 Mitochondrial glutamate acts as a messenger in glucose-induced insulin exocytosis. Nature 402 595-596.

Malaisse WJ, Sener A, Malaisse-Lagae F, Welsh M, Matthews DE, Bier DM \& Hellerstrom C 1982a The stimulus-secretion coupling of amino acidinduced insulin release: metabolic response of pancreatic islets of $\mathrm{L}_{\text {- }}$ glutamine and L-leucine. Journal of Biological Chemistry 257 8731-8737.

Malaisse WJ, Sener A, Malaisse-Lagae F, Welsh M, Matthews DE, Bier DM \& Hellerstrom C $1982 b$ The stimulus-secretion coupling of amino acidinduced insulin release. Journal of Biological Chemistry 257 8731-8737.

Molnar E, Varadi A, McIlhinney RAJ \& Ashcroft SJH 1995 Identification of functional ionotropic glutamate receptor proteins in pancreatic beta cells and in islets of Langerhans. FEBS Letter 371 253-257.

Murphy C \& Newsholme P 1998 The importance of glutamine metabolism in murine macrophages and human monocytes to L-arginine biosynthesis and rates of nitrite or urea production. Clinical Science 95 397-407.

Newsholme P, Procopio J, Ramos Lima MM, Pithon-Curi TC \& Curi R 2003 Glutamine and glutamate - their central role in cell metabolism and function. Cell Biochemistry and Function 21 1-9.

Prentki M \& Renold AE 1983 Neutral amino acid transport in isolated rat pancreatic islets. Journal of Biological Chemistry 258 14239-14244.
Rasschaert J, Flatt PR, Barnett CR, McClenaghan NH \& Malaisse WJ $1996 a$ D-Glucose metabolism in BRIN-BD11 islet cells. Biochemical and Molecular Medicine $\mathbf{5 7}$ 97-105.

Rasschaert J, Flatt PR, McClenaghan NH \& Malaisse WJ 1996 b Amino acid oxidation in BRIN-BD11 islet cells. Medical Science Research 24 691-692.

Renstrom E, Ding WG, Bokvist K \& Rorsman P 1996 Neurotransmitterinduced inhibition of exocytosis in insulin-secreting beta cells by activation of calcineurin. Neuron 17 513-522.

Schuit F, Halban P \& Rhodes C 2005 What is a beta cell and how can we improve it? Diabetologia 48 R93-R101.

Sener A, Mercan D \& Malaisse WJ 2001 Enzymic activities in two populations of purified rat islet beta-cells. International Journal of Molecular Medicine $\mathbf{8}$ 285-289.

Stanley CA, Lieu YK, Hsu BY, Burlina AB, Greenberg CR, Hopwood NJ, Perlman K, Rich BH, Zammarchi E \& Poncz M 1998 Hyperinulinism and hyperammonemia in infants with regulatory mutations of the glutamate dehydrogenase gene. New England Journal of Medicine 338 1352-1357.

Stanley CA, Fang J, Kutyna K, Hsu BYL, Ming JE, Glaser B \& Poncz M 2000 Molecular basis and characterization of the hyperinsulinism/hyperammonemia syndrome: predominance of mutations in exons 11 and 12 of the glutamate dehydrogenase gene. Diabetes 49 667-673.

Tanizawa Y, Nakai K, Sasaki T, Anno T, Ohta Y, Inoue H, Matsuo K, Koga M, Furukawa S \& Oka Y 2002 Unregulated elevation of glutamate dehydrogenase activity induces glutamine-stimultaed insulin secretionidentification and characterization of a GLUD1 gene mutation and insulin secretion studies with MIN6 cells overexpressing the mutant glutamate dehydrogenase. Diabetes $\mathbf{5 1} 712-717$.

Tietze F 1969 Enzymic method for quantitative determination of nanogram amounts of total and oxidize glutathione: applications to mammalian blood and other tissues. Annals of Biochemistry 27 502-522.

Webb GC, Akbar MS, Zhao C \& Steiner DF 2000 Expression Profiling of pancreatic beta cells: glucose regulation of secretory and metabolic pathway genes. PNAS 97 5773-5778.

Webb GC, Akbar MS, Zhao C \& Steiner DF 2001 Expression Profiling of pancreatic beta cells. Glucose regulation of secretory and metabolic pathway genes. Diabetes 50 S135-S136.

Wollheim CB 2000 Beta-cell mitochondria in the regulation of insulin secretion: a new culprit in type II diabetes. Diabetologia 43 265-277.

Yaney GC \& Corkey BE 2003 Fatty acid metabolism and insulin secretion in pancreatic beta cells. Diabetologia 46 1297-1312.

\section{Supplementary material}

Supplementary data table 1 associated with this article can be found in the online version of Journal of Endocrinology at http://joe.endocrinology-journals.org/content/vol190/issue3.

Received 28 March 2006

Received in final form 17 May 2006

Accepted 26 May 2006

Made available online as an Accepted Preprint 13 June 2006 